\title{
Corrigendum: Collective search by ants in microgravity
}

\author{
Stefanie M. Countryman ${ }^{1}$, Martin C. Stumpe ${ }^{2}$, Sam P. Crow ${ }^{3}$, Frederick R. Adler ${ }^{4}$, \\ Michael J. Greene ${ }^{5}$, Merav Vonshak ${ }^{6}$ and Deborah M. Gordon ${ }^{6 *}$
}

${ }^{1}$ BioServe Space Technologies, University of Colorado, Boulder, CO, USA, ${ }^{2}$ AnTracks Computer Vision Systems, Mountain View, CA, USA, ${ }^{3}$ Department of Computer Science and Engineering, University of Washington, Seattle, WA, USA, ${ }^{4}$ Department of Mathematics, University of Utah, Salt Lake City, UT, USA, ${ }^{5}$ Department of Integrative Biology, University of Colorado Denver, Denver, CO, USA, ${ }^{6}$ Department of Biology, Stanford University, Stanford, CA, USA

Keywords: collective search, behavior, ants, microgravity, robotics

\section{OPEN ACCESS}

Edited and reviewed by: James A. R. Marshall,

University of Sheffield, UK

*Correspondence: Deborah M. Gordon,

Department of Biology, Stanford University, Gillbert Biological Sciences Building, 371 Serra Mall, Stanford, CA 94305-5020, USA

dmgordon@stanford.edu

Specialty section:

This article was submitted to Behavioral and Evolutionary Ecology, a section of the journal Frontiers in Ecology and Evolution

Received: 28 April 2015 Accepted: 02 June 2015 Published: 19 June 2015

Citation: Countryman SM, Stumpe MC, Crow SP, Adler FR, Greene MJ, Vonshak M and Gordon DM (2015) Corrigendum:

Collective search by ants in microgravity. Front. Ecol. Evol. 3:62.

doi: 10.3389/fevo.2015.00062

\section{A corrigendum on}

Collective search by ants in microgravity

by Countryman, S. M., Stumpe, M. C., Crow, S. P., Adler, F. R., Greene, M. J., Vonshak, M., and Gordon, D. M. (2015). Front. Ecol. Evol. 3:25. doi: 10.3389/fevo.2015.00025

In the original article, the names of two authors in the following reference and citations were misspelled:

Collignan, B., Cervantes Valdivieso, L. I., and Detrain, C. (2014). Group recruitment in ants: who is willing to lead? Behav. Proc. 108, 98-104. doi: 10.1016/j.beproc.2014.09.033

"Collignon, B." was misspelled as "Collignan, B." and "Cervantes Valdivieso, L. E." was misspelled as "Cervantes Valdivieso, L. I."

The correct reference should be:

Collignon, B., Cervantes Valdivieso, L. E., and Detrain, C. (2014). Group recruitment in ants: who is willing to lead? Behav. Proc. 108, 98-104. doi: 10.1016/j.beproc.2014.09.033

Conflict of Interest Statement: The author declares that the research was conducted in the absence of any commercial or financial relationships that could be construed as a potential conflict of interest.

Copyright () 2015 Countryman, Stumpe, Crow, Adler, Greene, Vonshak and Gordon. This is an open-access article distributed under the terms of the Creative Commons Attribution License (CC BY). The use, distribution or reproduction in other forums is permitted, provided the original author(s) or licensor are credited and that the original publication in this journal is cited, in accordance with accepted academic practice. No use, distribution or reproduction is permitted which does not comply with these terms. 